\title{
A Study of Factors Affecting the Customers' Grocery Shopping Preferences in the Post Covid World
}

\author{
Dr. Vaishali Trivedi \\ Associate Professor, St. Kabir Institute of Professional Studies \\ drvaishali@skips.in \\ Mr. Ankit Chandani \\ PGDM Student, St. Kabir Institute of Professional Studies \\ ankit19@skips.in
}

\begin{abstract}
Internet revolution has completely transformed the way people buy around the world .Online shopping has emerged as the fastest growing shopping trend amongst the customers.This trend has been further accentuated by Covid-19 outbreak The pandemic has made customers rethink about the way they purchase various products including the groceries. This study intends to empirically investigate the factors which drive customers' grocery shopping preferences with respect to online /offline grocery retail platforms .
\end{abstract}

\section{Keywords}

Internet revolution, Covid -19, customers, grocery buying, online shopping,

\section{Introduction}

Covid -19 outbreak has changed the life of people across the world, upside down. It brought along with it, the fundamental changes in their lifestyle right from the way they work, they socialize and even the way the shop. One of the biggest problems that the people have been facing during the pandemic is with regards to grocery shopping since grocery items are a part of an individual's everyday necessities and thus have to be purchased frequently. For many middle-class households running short on cash flow, the shopping cart is typically less than half full during the so-called "Pandemic Shopping" due to partial pay receipts .Grocery retail players have been struggling on various fronts to respond to an unparalleled demand surge that has plagued the environment as a whole. Customers from all ages have moved to digital grocery platforms ushering in a new normal that may become irreversible for grocery retail. This has created an innovation-oriented retail environment, with the need to realign supply chains, redefine various aspects of the retail workforce according to the relevance and develop 
a deeper understanding of how to communicate via social media with loyal consumers.

In tough times like these, a growing number of retailers are aiming to tap a larger customer base by selling across various outlets, including both bricks and mortar and online retail . New innovations are now transforming the way that goods and services are paid for by customers. The provision of credit, distribution services, consulting services, stylist services and a number of other support services can also provide retail support services.

Many of the trends have changed due to Covid-19 in, grocery shopping is also set for a paradigm shift which is going to persist even after the pandemic is over.This study intends to investigate the factors which drive customers' grocery buying preferences with respect to online /offline grocery retail platforms .

\section{Objectives of the Study}

- To understand the customers' grocery buying preferences with respect to online /offline grocery retail platforms .

- To examine the impact of purchase convenience on customer's preference for online grocery shopping .

- To analyse the impact of opportunity of physical inspection of product on customer's preference for offline grocery shopping.

- To identify the impact of safety perception on customer online/offline grocery shopping.

\section{Review of Literature}

Review of the existing literature from international/national journals, conferences, books, and reports based on relevant concepts.

\section{Introduction to Online Grocery Shopping During Covid -19}

The daily needed food items that we buy from a supermarket or grocers are groceries. Few segments of groceries products are Pantry Items like grains, canned goods, bread and cereals, meat products, Dairy case, Spices and many more (Singhal 2020). Covid-19 being an event for a certain (yet not defined) period of time, the consumer perception is prone to change back to traditional sources and ways of acquiring groceries. It played a temporary yet vital role for growth and acceptability of the sector, as the sense of urgency brought in due to Covid-19 introduced online grocery platforms to a huge range of buyers who were reluctant to use it earlier. (Swastika Jain 2020). According to a RedSeer2 report, the share of online grocery in the total retail market in India will grow to 7\% by 2023. (Sownmyanarayanan 2020)

Buying something online with the use of electronic media via websites or emails without any physical presence can be known as online shopping. Online shopping has brought the 
traditional shop into your pocket. With just one click one can now easily purchase goods from worldwide. It has removed the hindrance of place and time. (Singhal 2020).

\section{Comparative study of online and offline Marketplace}

There has been a change in the relevance of factors that influence the customers to shop online or offline since Covid 19. Prior to the Covid-19 outbreak, factor such as touch and feel of the product was the topmost influencer for a consumer to purchase offline whereas in the current pandemic situation, it is the instant gratification of the products that is influencing the consumers to purchase offline. This suggests that importance of touch and feel of the product has now gone down and the consumers in the current scenario are ready to purchase packaged goods by reputed brands, which are standardized across outlets, hence the touch and feel doesn't matter in the current scenario. Second important factor is physical comparison of goods encouraging offline grocery shopping.

\section{Attitude and Perception of consumer towards online shopping}

While the globe has been revolving from the special effects of the Coronavirus (COVID19) pandemic, at the same time customer behaviour is being enforced to change and consumers are progressively moving towards online shopping. (Anupam Sharma 2020). Wrote a research paper on the attitude of consumers towards the acceptance rate of the online grocery market in India. Consumer behaviour towards online grocery shopping is not one time behaviour, it is routine behaviour of the consumer, the result revealed that family income, education level, age and working status affected the choice of consumers to shift online according to them. On the other hand, some of the consumers avoided online shopping. Online grocery markets were the concern about quality, unfamiliarity with online sites, internet speed and other technical barriers. Consumer review, feedback and social influence also had some influence on consumers and they are some of the main factors responsible for the rejection of decisions. (Harjinder Kaur 2017), (Singhal 2020). The attitude of consumers towards online grocery shopping in India is influenced by four factors: Perceived Cost, Perceived Convenience, Perceived Danger and Perceived Enjoyable. Consumers are also more concerned about product quality among the numerous fear factors related to online grocery shopping, though online grocery shopping has less social impact factors. Customers are happy with their online shopping experiences and positive attitudes towards them, but there are still many customers who are apprehensive about electronic purchases and share their personal details. (Mude 2020)

\section{New Opportunities for E- Grocers}

As reported in Economic Times, Due to the pandemic and lockdown, while sales on online grocery sites such as Grofers and Big Basket increased, aggregators like Zomato, Swiggy, and Jio-Mart also started delivering groceries.

Amazon and Flipkart have also seen an increase in grocery orders. Big Basket says that since March, its new customer acquisition grew three-fold in terms of orders, compared to 
pre COVID, while retention of new customer cohorts has increased by $60 \%$. Food delivery apps have teamed up with kirana stores and even farmers to sell groceries and local produce.

Throughout the lockdown and now WFH, people have been experimenting in their kitchen, and hence grocery orders have gone up. And not just pastas or cakes, sales of ingredients for traditional Indian dishes have increased. Due to an increase in grocery shopping, ecommerce websites have extended extra discounts, bank offers, and special deals to groceries shopping. (Lal 2020)

\section{Research Methodology}

This empirical study was conducted in the state of Gujarat during the period of October November 2020. For this study primary as well as secondary sources of data have been referred to. Non probability convenience sampling was carried out to determine sample size, which came out to be 166 using the formula $N=Z^{2} * \sigma^{2} / c^{2}$, where $Z=90 \%=1.64, \sigma=0.5$ and $\mathrm{c}=5 \%$. A structured questionnaire had been administered to record the preferences of the respondents.

\section{Data Analysis}

For the responses collected, Anova has been applied for testing the following hypothesis:

Table 5.1 Anova Output Table

\begin{tabular}{|c|c|c|c|}
\hline Sr. No. & 1 & 2 & 3 \\
\hline Hypothesis & $\begin{array}{l}\text { Ho1:- There is no } \\
\text { significant impact of } \\
\text { purchase convenience } \\
\text { on Customers' } \\
\text { preference for online } \\
\text { grocery shopping. } \\
\text { Ha1:- There is a } \\
\text { significant impact of } \\
\text { purchase convenience } \\
\text { on Customers' } \\
\text { preference for online } \\
\text { grocery shopping. }\end{array}$ & $\begin{array}{l}\text { Ho2:- There is no } \\
\text { significant impact of } \\
\text { opportunity of physical } \\
\text { inspection of product } \\
\text { on customers' } \\
\text { preference for offline } \\
\text { grocery shopping. } \\
\text { Ha2:- There is a } \\
\text { significant impact of } \\
\text { opportunity of physical } \\
\text { inspection of product } \\
\text { on customers' } \\
\text { preference for offline } \\
\text { grocery shopping. }\end{array}$ & $\begin{array}{l}\text { Ho3:- There is no } \\
\text { significant impact of } \\
\text { safety perception on } \\
\text { customers' } \\
\text { online/offline grocery } \\
\text { shopping. } \\
\text { Ha3:- There is a } \\
\text { significant impact of } \\
\text { safety perception on } \\
\text { customers' } \\
\text { online/offline grocery } \\
\text { shopping. }\end{array}$ \\
\hline F value & 163.9269 & 287.4806 & 200.4915 \\
\hline p-value & 0.032 & 0.04 & 0.023 \\
\hline Result & $\begin{array}{l}\text { Ho1 Rejected } \\
\text { Ha1 Accepted }\end{array}$ & $\begin{array}{l}\text { Ho2 Rejected } \\
\text { Ha2 Accepted }\end{array}$ & $\begin{array}{l}\text { Ho3 Rejected } \\
\text { Ha3 Accepted }\end{array}$ \\
\hline
\end{tabular}




\section{Findings}

The major finding from this research based on hypothesis testing was that safety perception significantly influences the choice of the customer to buy online or offline amidst the pandemic. Another major finding identified is that convenience is seen as one of the primary reason driving the respondents to buy from online grocery retail chains. On the other front, the opportunity to physically inspect the products while buying is seen to impact the customers' decision to buy from offline grocery stores significantly.

\section{Managerial Implications}

Based on the findings from analysis, it is recommended for all the retail outlets as well as online grocery delivery apps to take adequate steps to enhance the safety aspects of their service Contactless delivery, Proper packaging and sanitization, etc. things should be kept in mind while operating and also while designing marketing communications for the customers at large. Also online grocery retail platforms must introduce more of innovative "Try and Buy " purchase mechanism so as to provide an opportunity to the customers' to inspect the products virtually and physically as well which instills greater confidence in them with respect to their buying options. Offline grocery stores must take adequate steps by adopting suitable "Phygital" approaches to enhance the buying experience and ease of their customers'.

\section{References}

1) Dannenberg, P., Fuchs, M., Riedler, T., \& Wiedemann, C. (2020). Digital transition by COVID-19 pandemic? The German food online retail. Tijdschrift voor economische en sociale geografie, 111(3), 543-560.

2) Ezeala-Harrison, F., \& Baffoe-Bonnie, J. (2016). Market concentration in the grocery retail industry: Application of the basic prisoners' dilemma model. Advances in Management and Applied Economics, 6(1), 47.

3) Javadi, M. H. M., Dolatabadi, H. R., Nourbakhsh, M., Poursaeedi, A., \& Asadollahi, A. R. (2012). An analysis of factors affecting on online shopping behavior of consumers. International Journal of Marketing Studies, 4(5), 81.

4) Caplice, Chris and Yossi Sheffi (1995), "A Review and Evaluation of Logistics

5) Performance Measurement Systems." The International Journal of Logistics Management, Vol. 6, No.1 (1995), pp. 61-74. 
SKIPS ANVESHAN VOL 2 IsSUe I July 2021 (ISSN No. 2582-4236) 